\title{
PERBANDINGAN KARAKTER TOKOH UTAMA \\ NOVEL SALAH ASUHAN KARYA ABDOEL MOEIS \\ DAN BELENGGU KARYA ARMIN PANE
}

\author{
Poni Ernis ${ }^{1)}$ \\ ${ }^{1)}$ STKIP Yayasan Abdi Pendidikan Payakumbuh \\ poni84ernis@gamail.com
}

\begin{abstract}
ABSTRAK
Penulis tertarik meneliti kedua novel ini karena ingin mengetahui bagaimanakah perbandingan karakter tokoh utama dan persamaan maupun perbedaan dari kedua novel tersebut. Alasan membandingkan dua novel dari penerbit yang berbeda karena 1) beda penerbit dan 2) beda karakter, balai pustaka menerbitkan novel yang bertema kawin paksa dan adat, sedangkan pujangga baru bersifat masyarakat modern. Jenis penelitian kualitatif dengan metode deskriptif. Objek penelitian ini novel adalah Salah Asuhan dan Belenggu. Instrumen peneliti sendiri dan istrumen tambahan seperti pena dan buku. Langkah-langkah pengumpulan data sebagai berikut 1) membaca dan memahami isi kedua novel yang akan diteliti 2) menginventarisasi dan mengklasifikasikan data tokoh dan karakter tokoh utama berdasarkan aspek karakter tokoh dengan menggunakan format 3) menganalisis data yang telah diklasifikasikan 4) membahas dan membandingkan karakter tokoh utama yang meliputi sifat, sikap, dan tingkah laku 5) menyimpulkan hasil penelitian. Hasil penelitian tentang perbandingan karakter tokoh utama novel Salah Asuhan dan Belenggu terdapat 106 data, dalam novel Salah Asuhan terdapat 49 data terdiri atas 23 data sifat, 12 data sikap, dan 14 data tingkah laku. Novel Belenggu terdapat 57 data terdiri atas 22 data sifat, 20 data sikap, dan 15 data tingkah laku.
\end{abstract}

Kata kunci: Karakter, tokoh utama, novel

\section{PENDAHULUAN}

anusia merupakan objek dalam kehidupan ini. Setiap manusia dalam kehidupannya memiliki karakter yang berbeda-beda, begitu pula dalam karya sastra. Seorang pengarang akan menggambarkan tokoh dalam karyanya dengan karakter yang berbeda-beda pula. Karakter yang biasanya ditonjolkan oleh pengarang adalah karakter baik dan karakter buruk. Karakter baik adalah semua perbuatan yang baik dan tidak menentang aturan agama maupun norma yang ada. Sedangkan, karakter buruk adalah kebalikan dari karakter yang baik. Semua yang diperlihatkan adalah tindakan, percakapan atau 
PONI Ernis : PERBANDINGAN KARAKTER TOKOH UTAMA NOVEL SALAH ASUHAN KARYA ABDOEL MOEIS DAN BELENGGU KARYA ARMIN PANE

Website : https://jurnal.umj.ac.id/index.php/penaliterasiEmail : penaliterasi@umj.ac.id

pernyataan yang mencerminkan bahwa karakter tokoh itu buruk.

Pada novel Salah Asuhan diceritakan tentang kisah percintaan antara Hanafi dan Corrie. Kisah percintaan mereka tidak berjalan dengan mulus karena Corrie menolak cinta Hanafi, mereka di tentang oleh ayah Corrie, dan Hanafipun dijodohkan dengan Rapiah, anak dari mamak Hanafi. Setelah Hanafi menikah dengan Rapiah, Hanafi bertemu lagi dengan Corrie, dan akhirnya Hanafi menjadikan Corrie sebagai istri kedua, tapi sayangnya pernikahan mereka tidak harmonis. Hanafi bunuh diri setelah Corrie meninggal dunia terlebih dahulu. Pada novel Belenggu diceritakan tentang kehidupan rumah tangga antara dokter Sukartono dan Tini yang tidak pernah harmonis. Rumah tangga mereka selalu diwarnai dengan percekcokan dan lebih mengutamakan ego masing-masing. Akhirnya dokter Sukartono merasakan kehangatan melalui Yah atau Siti Rohayah dan merasa lebih dihargai. Kemudian, dokter Sukartono menjalin hubungan dengan Yah tanpa sepengetahuan istrinya. Hubungan mereka akhirnya diketahui oleh Tini dan mereka berpisah. Sementara itu, Yah memutuskan untuk pergi dari kehidupan dokter Sukartono.

Abdoel Moeis adalah seorang sastrawan yang mempunyai banyak bakat, dimana beliau selain seorang sastrawan, Abdoel Moeis juga seorang politikus dan wartawan. Satu hal yang paling istimewa dari Abdoel Moeis seorang sastrawan dari Minangkabau. Pada novel Salah Asuhan, pengarang mencoba membahas celah adat barat dan timur yang bercampur di kota Solok. Selain itu, pengarang berusaha menggambarkan kelas sosial yang berbedabeda dan penulis menyatakan bahwa manusia itu sama. Penulis juga menggambarkan betapa angkuhnya manusia, dimana manusia bisa lupa diri karena cinta. Selain itu, pengarang menulis novel dengan baik, sehingga pembaca dapat larut dan ikut merasakan apa yang dirasakan oleh tokoh di dalam novel tersebut.
Armin Pane adatah seorang sastrawan yang juga mempunyai banyak bakat, banyak hal yang Armin Pane lakukan dan kerjakan. Armin Pane mengajar bahasa dan sejarah di sekolah kebangsaan Jakarta, Armin Pane juga seorang yang istimewa, sehingga Armin Pane menerima penghargaan Anugerah Seni dari RI pada tahun 1969. Pada novel Belenggu, novel ini merupakan novel yang mempunyai sejarah menggemparkan. Karena pernah ditolak oleh Balai Pustaka, ramai dipuji dan dicela. Namun akhirnya menjadi salah satu novel yang harus dibaca oleh semua kalang terpelajar. Selain itu, pengarang menyajikan konflik yang ada dengan menarik sehingga pembaca dapat terbawa ke dalam karyanya.

Melihat banyaknya hal yang menarik dari kedua novel di atas, maka penulis tertarik untuk menelitinya. Selain itu, penulis tertarik meneliti kedua novel di atas karena ingin mengetahui bagaimanakah perbandingan karakter tokoh utama dan persamaan maupun perbedaan dari kedua novel tersebut. Penelitian ini penting untuk diteliti karena kedua novel tersebut memiliki keistimewaan dan mengkaji tentang masalah kehidupan yang jalani dengan konflikkonflik yang menarik. Apalagi dilihat dari cara kedua pengarang menggambarkan penokohannya yang sama-sama memakai metode analitik atau secara langsung, yaitu pengarang menggambarkan watak-watak tokoh secara langsung. Tujuan dari penelitian mendeskripsikan perbandingan karakter tokoh utama novel Salah Asuhan karya Abdoel Moeis dan Belenggu karya Armin Pane, yang meliputi, sifat, sikap dan tingkah laku.

\section{A. Karya Sastra}

\section{Pengertian Novel}

Menurut Suhendar dan Supinah (1993:154) menyatakan novel adalah cerita prosa dalam ukuran yang luas, menguraikan peristiwa kehidupan seseorang yang luar biasa, dan berakhir dengan perubahan nasib kehidupan pelakunya. Kosasih (2003:250) mengemukakan Novel berasal dari bahasa Italia novella yang berarti sebuah barang baru yang 
PONI Ernis : PERBANDINGAN KARAKTER TOKOH UTAMA NOVEL SALAH

ASUHAN KARYA ABDOEL MOEIS DAN BELENGGU KARYA ARMIN PANE

Website : https://jurnal.umj.ac.id/index.php/penaliterasiEmail : penaliterasi@umj.ac.id

kecil. Kemudian kata itu diartikan sebagai sebuah karya sastra dalam bentuk prosa.

\section{Unsur Intrinsik Novel}

Menurut Nurgiyantoro

(1995:23)

mengemukakan unsur intrinsik adalah unsurunsur yang membangun karya sastra itu sendiri seperti, amanat, sudut pandang, plot, tema, latar, gaya bahasa dan penokohan. Ruskhan dkk (2008:544) mengemukakan intrinsik adalah terkandung di dalamnya. Unsur intrinsik dalam novel: Amanat, Sudut Pandang, Plot, Tema, Latar, Gaya Bahasa, dan Penokohan

Menurut Jones (dalam Nurgiyantoro, 1995:165) menyatakan bahwa penokohan adalah pelukisan gambaran yang jelas tentang seseorang yang ditampilkan dalam sebuah cerita. Kosasih (2003:256) mengemukakan penokohan adalah cara pengarang menggambarkan dan mengembangkan karakter tokoh-tokoh dalam cerita. Siswanto (2008:142) menyatakan bahwa tokoh dalam karya rekaan selalu mempunyai sifat, sikap, tingkah laku atau watak-watak tertentu.

\section{Tokoh}

Kokasih (2003:256) menyatakan bahwa ponokohan adalah cara pengarang menggambarkan dan mengembangkan karakter tokoh-tokoh dalam cerita. Berdasarkan pendapat tersebut, dapat disimpulkan tokoh adalah orang atau pelaku dalam cerita yang mengemban peristiwaperistiwa yang ada dalam cerita tersebut. Peristiwa-peristiwa yang dialami oleh tokoh tersebut akan menghasilkan cerita yang bagus.

\section{a) Tokoh Utama}

Menurut Nurgiyantoro (1995:176-177) mengemukakan tokoh utama adalah tokoh yang diutamakan penceritaannya dan paling banyak diceritakan, baik sebagai pelaku kejadian maupun yang dikenai kejadian. Ruskhan dkk (2008:1476) menyatakan tokoh utama adalah peran utama dalam cerita rekaan atau drama.
Tokoh utama merupakan tokoh yang paling banyak disukai oleh pembaca.

\section{b) Karakter}

Ruskhan dkk (2008:623) menyatakan karakter adalah sifat-sifat kejiwaan, akhlak atau budi pekerti yang membedakan seseorang dengan yang lain. Berdasarkan pendapat tersebut, dapat disimpulkan bahwa karakter merupakan suatu sikap, emosi, dan perbuatan dari tokoh yang diceritakan oleh pengarang. Cara mengungkapkan karakter tersebut dapat dilihat melalui pernyataan langsung, melalui peristiwa, percakapan, atau perbuatan tokoh dalam karya sastra. Karakter seorang tokoh akan terlihat melalui sifat, sikap, dan tingkah lakunya. Uraiannya adalah sebagai berikut ini.

\section{(1) Sifat}

Menurut Ruskhan dkk (2008:1302) menyatakan sifat adalah dasar watak (dibawa sejak lahir), tabiat. Berdasarkan pendapat tersebut, dapat disimpulkan sifat adalah rupa, keadaan, ciri, tanda yang tampak pada suatu benda atau keadaan yang menurut kodratnya ada pada suatu orang, dasar watak atau tabiat dari seseorang yang telah dibawa sejak lahir

\section{(2) Sikap}

Menurut Bruno (dalam Syah, 2007:123) sikap adalah kecenderungan yang relatif menetap untuk bereaksi dengan cara baik atau buruk terhadap orang atau barang tertentu. Ruskhan dkk (2008:1303) Sikap adalah perbuatan dan sebagainya yang berdasarkan pada pendirian, dan keyakinan). Berdasarkan pendapat tersebut, dapat disimpulkan sikap adalah suatu perbuatan dan sebagainya yang dilakukan oleh seseorang berdasarkan pada pendirian, pendapat atau keyakinan dari orang tersebut, yang akan menjadi satu dengan tingkah laku mereka.

\section{(3) Tingkah Laku}

Menurut Syah (2007:253) tingkah laku adalah perbuatan yang menyangkut keanekaragaman perasaan, seperti takut, marah, sedih, gembira, kecewa, senang, benci, waswas, dan sebagainya. Daradjat dkk, (2008:266) 
PONI Ernis : PERBANDINGAN KARAKTER TOKOH UTAMA NOVEL SALAH

ASUHAN KARYA ABDOEL MOEIS DAN BELENGGU KARYA ARMIN PANE

Website : https://jurnal.umj.ac.id/index.php/penaliterasiEmail : penaliterasi@umj.ac.id

menyatakan bahwa Tingkah laku adalah sikap seseorang yang dimanifestasikan ke dalam perbuatan. Berdasarkan pendapat tersebut, dapat disimpulkan bahwa tingkah laku adalah sikap, kelakuan seseorang yang dimanifestasikan ke dalam perbuatan.

\section{B. Studi Komparatif}

Menurut Daradjat dkk, (2008:719) menyatakan bahwa komparatif adalah berkenaan atau berdasarkan perbandingan. Berdasarkan pendapat di atas, dapat disimpulkan penelitian komparatif atau penelitian perbandingan merupakan suatu penelitian yang membandingkan dua atau lebih karya sastra. Penelitian ini bertujuan untuk mengetahui persamaan dan perbedaan antara karya sastra yang dibandingkan tersebut.

\section{Pendekatan Analisis Fiksi}

Meneliti sebuah karya sastra memerlukan suatu pendekatan penelitian sastra. Oleh karena itu, peneliti akan menggunakan pendekatan objektif untuk meneliti. Menurut Muhardi dan Hasanuddin (1992:40) mengemukakan pendekatan analisis fiksi merupakan suatu strategi untuk memahami dan menjelaskan temuan tentang fiksi yang diselidiki yang menuntut proses kerja sistematis dan objektif dengan landasan berfikir logis. Selanjutnya, Muhardi dan Hasanuddin (1992:47) menyatakan pendekatan objektif dalam penganalisisannya hanya bertumpu pada teks karya fiksi semata dan lepas dari unsur-unsur luar yang mempunyai andil dalam penciptaan sebelumnya.

\section{METODE PENELITIAN}

$\mathrm{J}$ enis penelitian ini adalah penelitian kualitatif dengan metode deskriptif. Moleong (2005:6) mengemukakan penelitian kualitatif adalah penelitian yang menghasilkan prosedur analisis yang tidak menggunakan prosedur analisis statistik atau cara kuantifikasi lainnya. Melalui penelitian ini, secara deskriptif penulis akan menguraikan tentang perbandingan karakter tokoh utama novel Salah Asuhan karya Abdoel Moeis dan Belenggu karya Armin Pane.

Objek penelitian ini adalah novel Salah Asuhan karya Abdoel Moeis. Novel ini merupakan novel yang telah terbit sampai pada cetakan ke-31. Di sini peneliti akan meneliti novel pada cetakan ke-31 yang terdiri dari 242 halaman dengan penerbit Balai Pustaka. Kemudian novel Belenggu karya Armin Pane merupakan novel yang telah terbit sampai pada cetakan ke-21.

Instrumen penelitian adalah peneliti sendiri yang di bantu oleh instrumen tambahan seperti pena dan buku. Yang melakukan keseluruhan proses penelitian yang dimulai dari perencanaan sampai membuat laporan penelitian.

Teknik pengumpulan data yang dilakukan penulis untuk menganalisis novel Salah Asuhan karya Abdoel moeis dan Belenggu karya Armin Pane tentang perbandingan karakter tokoh utama adalah (1) Membaca dan memahami isi kedua novel yang akan diteliti. (2) Menandai kalimat yang menunjukkan karakter pada tokoh. (3) Mengkalisifikasikan data. (4) Melaporkan hasil penelitian.

Teknik analisis data dengan langkahlangkah sebagai berikut: (1) Menganalisis data yang telah diklasifikasikan, (2) membahas dan membandingkan karakter tokoh utama yang meliputi sifat, sikap, dan tingkah laku, dan (3) menyimpulkan hasil penelitian.

Teknik pemeriksaan keabsahan data dalam penelitian ini, peneliti menggunakan teknik triangulasi sumber. Moleong (2005:330) mengemukakan triangulasi adalah teknik pemeriksaan keabsahan data yang memanfaatkan sesuatu yang lain. Triangulasi sumber yang digunakan untuk menguji data dalam penelitian ini adalah dosen pembimbing dari peneliti sendiri. 
PONI Ernis : PERBANDINGAN KARAKTER TOKOH UTAMA NOVEL SALAH

ASUHAN KARYA ABDOEL MOEIS DAN BELENGGU KARYA ARMIN PANE

Website : https://jurnal.umj.ac.id/index.php/penaliterasiEmail : penaliterasi@umj.ac.id

\section{HASHL DAN PEMBAHASAN}

\section{Karakter Tokoh Utama Novel Salah Asuhan Karya Abdoel Moeis Berdasarkan Sifat}

a. Hanafi

Sifat-sifat yang ada pada tokoh hanafih adalah Sifat-sifat yang ada pada tokoh Hanafi adalah pemarah, sombong, dan egois.

(1) Pemarah

"Hanafi, yang berasa naik darah, melihat pula kearah pemandangan sudut mata itu." (9/12).

Kutipan tersebut menjelaskan bahwa Hanafi bersifat pemarah. Terlihat pada saat Corrie bercanda, Hanafi malah menanggapi serius gurauan Corrie! Sifat pemarah ini merupakan dasar watak Hanafi,

(2) Sombong

"Uah, keluaran sekolah raja model kuno, waktu tidak di ajarkan bahasa Belanda."(33/2).

Kutipan tersebut menjelaskan Hanafi bersifat sombong, karna dia disekolahkan di sekolah Belanda, sehingga dia merasa lebih pandai dari pada mamaknya yang lulusan sekolah biasa. Suka menganggap orang lain lebih rendah derajatnya pada dia merupakan sudah menjadi dasar watak Hanafi.

(3) Egois

"Jika demikian duduknya, baiklah mereka menghitung jumlah hutangku itu, supaya boleh di angsur bayarnya."(32/2).

Kutipan tersebut menjelaskan sifat Hanafi yang egois, yang ingin menang sendiri, tak mau menghiraukan orang lain, merasa hutang budi bisa dia bayar dengan uang dia, tampa dia berfikir bahwa bukan uanglah yang dibutuhkan mamaknya, tapi bayarlah dengan budi juga, dengan mempersunting Rapiah.

b. Corrie

Sifat-sifat yag ada pada tokoh Corrie adalah jinak-jinak merpati, tegas, egois dan keras kepala.
(1) Jinak-jinak merpati

"Sebagai lakumu selama ini, bagaikan jinak-jinak merpati”. $(12 / 1)$

Kutipan tersebur menjelaskan sifat Corrie selalu tenang tatapi waspada, karena dia suka bergaul dengan semua orang, tapi tidak mudah untuk dapatkan menjadinya sebagai kekasih. Karna menang sudah menjadi sifat Corrie yang tak mudah terayu.

(2) Tegas

"Hingga ini keatas pikiran yang sehat saja yang harus berlaku". (47/9).

Kutipan tersebut menggambarkan sifat Corrie yang tegas, terlihat pada saat Corrie sedang berbicara dengan Hanafi. Dimana Corrie berkata mulai dari sekarang dan seterusnya akan seperti itu, tidak bisa dirubah lagi.

(3) Keras hati

"Hanya sayang Corrie berhati batu, tidak mengampuni kesalahan orang, yang sudah diterimanya sebagai suami”. (189/2)

Kutipan tersebut menjelaskan sifat Corrie yang keras hati, hal ini terbukti dari ucapan Hanafi kepada Temannya saat membicarakan kepergian Corrie dari rumah akibat kesalah pahaman Hanafi yang telah menuduh Corrie selingkuh.

c. Rapiah

Sifat-sifat yang ada pada tokoh Rapiah adalah sabar, dewasa, dan baik hati.

(1) Sabar

"Rapiah sedang meremas Kelapa dan sambil melihat dengan air muka yang jernih pada suaminya."(80/5).

Kutipan tersebut menjelaskan sifat Rapiah yang sabar, menghadapi suami yang cuma bisa marah, membentak dan mencacimaki Rapiah saja.

(2) Dewasa 
PONI Ernis : PERBANDINGAN KARAKTER TOKOH UTAMA NOVEL SALAH

ASUHAN KARYA ABDOEL MOEIS DAN BELENGGU KARYA ARMIN PANE

Website : https://jurnal.umj.ac.id/index.php/penaliterasiEmail : penaliterasi@umj.ac.id

"Meskipun Rapiah masih anak muda, tapi ujud kata mentuanya itu difahamkannya benar.'(125/1).

Kutipan tersebut menjelaskan sifat Rapiah yang dewasa, mempunyai pemikiran yang dewasa dalam setiap kali perkataan dia pahami maksud dan tujuan mertuanya berbicara padanya, agar dia tidak salah paham dan salah makna dari setiap kali ucapan mertuanya.

(3) Baik hati

"Segala orang yang sudah bergaul dengan dia mengaku, bahwa anak itu sudah bersifat wali, bukanlah bersifat manusia lagi”. (84/9)

Kutipan tersebut menjelaskan sifat Rapiah yang baik hati, terbukti dari ucapan tokoh lain yang berpendapat mengenai diri Rapiah yang mempunyai hati yang baik.

\section{Karakter Tokoh Utama Novel Salah Asuhan Karya Abdoel Moeis Berdasarkan Sikap}

a. Hanafi

Sikap-sikap yang ada pada tokoh Hanafi adalah sombong dan pemarah.

(1) Sombong

"Itulah salahnya, ibu, bangsa kita dari kampung; tidak suka menurutkan putaran jaman. Lebih suka duduk rungkuh dan duduk mengukul saja sepanjang hari. Tidak ubah dengan kerbau bangsa kita, Bu! Dan segala sirih menyirih itu."(29/4).

Kutipan tersebut menjelaskan bahwa Hanafi bersikap sombong, merasa bangga hati dengan dirinya yang di asuh orang Belanda, sehingga tidak suka dengan adanya adat Minangkabau.

(2) Pemarah

"Setiap hari, asal saja sudah menimbulkan amarahnya, perkara itu sedah dipakainya buat melepaskan sakit hatinya kepada rapiah."(hal/parg, 78/3).
Kutipan tersebut menjelaskan sikap

Hanafi yang pemarah kepada Rapiah, setiap kali dia merasa ada masalah di tempat kerja atau masalah apapun, dia limpahkan kemarahannya kepada Rapiah.

b. Corrie

Sikap-sikap yang ada pada tokoh Corrie adalah cuek, bebas, penjijik dan dingin.

(1) Cuek

"Sedikitpun Corrie tidak mengindahkan 'ratap dan tangis dari segala pihak itu, ancaman hendak meninggalkan dunia air mata' ini dibacanya dengan gelak terbahak-bahak seorang dirinya. "(18/3).

Kutipan tersebur menjelaskan sikap Corrie yang cuek, terlihat dari sikap Corrie yang tak mau menghiraukan perasaan para laki-laki yang tertarik pada dirinya.

(2) Bebas

"Tapi Corrie hendak bermaksud membalas surat-surat itu, hendak diterangkannya, bahwa iya sekali-kali tidak bermaksud hendak bersuami, karena hidup bersuami-istri itu tiadalah menarik hatinya". (49/4)

Kutipan tersebut menjelaskan sikap Corrie yang suka kebebasan, dimana Corrie sebenarnya tidak pernah ingin untuk menikah, karna pernikahan akan mengurung kebebasan hidup dia.

(3) Jijik

"Bahwa sesungguhnya Corrie sudah berasa geli akan bersinggung dengan laki-laki". ( 49/5)

Kutipan di atas menjelaskan sikap Corrie yang merasa jijik terhadap sentuhan laki-laki, dia pun tak memahami alasannya.

c. Rapiah 
PONI Ernis : PERBANDINGAN KARAKTER TOKOH UTAMA NOVEL SALAH

ASUHAN KARYA ABDOEL MOEIS DAN BELENGGU KARYA ARMIN PANE

Website : https://jurnal.umj.ac.id/index.php/penaliterasiEmail : penaliterasi@umj.ac.id

Sikap yang ada pada tokoh Rapiah

adalah tidak malu.

"Rapiah memang sudang
kehilangan getar dan malu,
memperlihatkan rupa seperti itu
kesahabat-sahabat
suaminya."(82/6).
Kutipan tersebut menjelaskan sikap
Rapiah yang sudah tidak malu, akan anggapan sahabat Hanafi terhadap dirinya yang datang dari dapur dengan pakaian yang terlihat kumuh seperti pembantu saat mendengar anaknya menjerit digendong Hanafi.

\section{(3) Karakter Tokoh Utama Novel Salah Asuhan Karya Abdoel Moeis Berdasarkan Tingkah Laku}

a. Hanafi

Tingkah laku yang ada pada tokoh Hanafi adalah merayu dan sombong.

(1) Merayu

"Setelah ia memandang sejurus lamanya pada mata gadis itu, maka digenggamlah kelima jarinya tangan Corrie yang sedang meraba tangannya itu, lalu diciumnya punggung tangan si gadis itu." (7/12).

Kutipan tersebut menjelaskan bahwa tingkah laku Hanafi sedang merayu Corrie, terlihat disaat mereka sedang duduk berdua di lapangan tenis, Hanafi tiba-tiba meraba dan menggenggam jari-jari tangan.

(2) sombong

"Pakaian cara Belanda, pergaulannya dengan Belanda saja. Jika ia berbahasa Melayu, meskipun dengan ibunya sendiri, maka dipergunakannya bahasa Riau, dan kepada orang yang dibawahnya ia berbahasa cara orang Betawi. Begitupun juga sebagai dipatah-patahkannya lidahnya dalam berbahasa sendiri."(29/5).
Kutipan tersebut menjelaskan tingkah

laku Hanafi yang sombong, sudah berubah menjadi seperti orang Belanda, dan merendahkan harga dirinya sendiri sebagai bumiputra.

\section{b. Corrie}

Tingkah laku yang ada pada tokoh Corrie adalah waspada, salah tingkah dan kekanak-kanakan.

(1) Waspada

"Corrie tinggal bermulut manis pada sekaliannya, tapi jika perangai mereka serupa hendak melampaui baris, maka dengan segala manisnya pula Corrie seolah-olah membangun benteng yang teguh membatasi mereka, hingga tak ada yang berani mendekatinya."(19/1).

Kutipan tersebut menjelaskan tingkah laku Corrie yang selalu waspada terhadap rayuan laki-laki, sehingga membuat sebagian laki-laki tak berani mendekatinya.

(2) salah tingkah

"Dari pukul empat Corrie sudah berhias dan memakai di muka cermin besar. Mula-mula dipakainya baju biru laut, yaitu warna yang sangat disukainya, teringatlah oleh dia warna yang disukai oleh Hanafi adalah lila". (42/1)

Kutipan tersebut menggambarkan tingkah laku Corrie sedang salah tingkah, terlihat dengan cara Corrie menggonta-ganti pakaiannya saat ingin bertemu dengan Hanafi.

(3) Kekanak-kanakan

"Benar, Han; meskipun aku masih berperangai kekanak-kanak di dalam beberapa hal sampai dalamlah pula pikiranku". (132/3)

Kutipan tersebut menggambarkan Corrie masih bertingkah laku kekanak-kanakan, terlihat dari ucapan Corrie sendiri.

c. Rapiah 
PONI Ernis : PERBANDINGAN KARAKTER TOKOH UTAMA NOVEL SALAH

ASUHAN KARYA ABDOEL MOEIS DAN BELENGGU KARYA ARMIN PANE

Website : https://jurnal.umj.ac.id/index.php/penaliterasiEmail : penaliterasi@umj.ac.id

Tingkah laku yang ada pada tokoh

Rapiah adalah bersedih dan terbawa suasana hati.

(1) Bersedih

"Tapi sekali itu Rapiah amat nyaring dan keras, sampai terdengar kedalam kebun. Rupaya dia sedang berhanyut-hanyut di bawa untungnya."(86/2).

Kutipan tersebut menjelaskan tingkah laku Rapiah yang sedang meratapi nasib atau bersedih, terlihat pada Rapiah yang terbawa suasana hatinya yang sedang sedih, sehingga suara dia bernyanyi meratapi nasib terdengar sampai ke kebun tampa dia sadari.

(2) Terbawa suasana

"Seketika itu tapisan santan pun sudah ditahankannya di atas belanga yang terjerang di atas tungku, sedang air matanya, menghilir dan berderaiderailah jatuh ke tanah". (113/3)

Kutipan tersebut menggambarkan tingkah laku Rapiah yang terbawa suasana hati yang kusut karna rindu terhadap Hanafi, sehingga dia tidak sadang dengan apa yang sedang dia lakukan saat itu.

\section{Karakter Tokoh Utama Novel Belenggu Karya Armin Pane Berdasarkan Sifat}

a. Dr. Sukartono

Sifat-sifat yang ada pada tokoh Dr. Sukartono adalah tanggung jawab, tidak pernah marah, suka seni, dan suka menolong.

(1) Tanggung jawab

"Saudaranya tau, sejak kecil, memang sudah begitu tabiat

Sukartono. Memang perasaan tanggung jawab keras padanya."(24/1).

Kutipan tersebut menjelaskan sifat Sukartono yang mempunya rasa tanggung jawab tinggi, jika dia telah diberi beban, maka dia dengan senang hati memikul tanggung jawabnya untuk saudarasaudaranya, karena memang sudah dari kecilnya sifatnya seperti itu.

(2) Tidak pemarah

"Tetapi ndoronya tidak pernah marah, bukankah sukanya juga, menunggu ndoronya kembali?.”(56/3).

Kutipan tersebut menjelaskan sifat Sukartono yang tidak pernah marah, sehingga membuat bujangnya selalu setia menanti kepulangan Sukartono dari rumah sakit maupun dari rumah pasien.

(3) Suka seni

"Waktu masih menuntut pelajaran disekolah Geneeskundige Hooge School Betawi, tiada sedikit kawankawan dokter Sukartono yang memastikan, dia tidak akan sampai ke ujian penghabisan. Dia tiada cakap jadi dokter, terlalu suka akan lagu, akan seni, pikiran terlalu banyak terlalai". (23/5)

Kutipan tersebut menjelaskan sifat Sukartono yang berjiwa seni, dinama Sukartono memang sudah dari dulunya suka akan seni.

(4) Baik

"Dokter biasanya banyak-banyak datang, biar banyak-banyaknya dapat duit, tetapi tuan dokter hendak lekas-lekas jangan datang lagi, sudah mengatakan".

27/8)

Kutipan tersebut menjelaskan sifat Sukartono yang baik, karena Sukartono menjadi dokter bukan hanya sekedar mencari rezeki saja, melainkan Sukartono juga bahagia jika pasiennya lekas sembuh, tidak berlama-lama sakit, dan tidak terus-menerus berobat.

(5) Suka menolong

"Apa perlunya ilmu, kalau tidak mendapat uang! Sangkamu aku belajar berpuasa? Tidak, Tono, aku bukan seperti engkau". (106/6) 
PONI Ernis : PERBANDINGAN KARAKTER TOKOH UTAMA NOVEL SALAH

ASUHAN KARYA ABDOEL MOEIS DAN BELENGGU KARYA ARMIN PANE

Website : https://jurnal.umj.ac.id/index.php/penaliterasiEmail : penaliterasi@umj.ac.id

Kutipan tersebut menjelaskan sifat

Sukartono yang suka menolong, karena ilmu yang dia punya sebagai dokter bukan sekedar digunakannya untuk mencari rezeki, tetapi sering juga dia sumbangkan bagi orang yang tidak mampu.

b. Tini

Sifat-sifat yang ada pada tokoh Tini adalah pemarah, egois dan pandai membuat orang bahagia.

(1) Pemarah

"Bukan kau bilang tiada usah dijemput? Siapa bilang? Bukan kau yang mengatakan hendak menjemput aku? Tini memandangnya dengan marah".(35/4).

Kutipan tersebut menjelaskan sifat Tini yang pemarah, tidak terima dengan perlakuan suaminya,

\section{(2) Egois}

"Tini tertawa; "Perlu, perlu! Keperluan itu bukan dibuat-buat?" "Ah, aku tiada mengerti jalan pikiranmu." "Memang, Ibu! Jalan pikiranku, menggembirakan hatiku. Aku manusia juga yang berkemauan sendiri. Bukan ibu, bukankah demikian? Kami masingmasing berkemauan sendiri-sendiri". $(53 / 4)$

Kutipan tersebut menggambarkan sifat Tini yang egois, terlihat saat bercakap dengan ibu, dia tidak mau mendengarkan apa kata ibu itu, dia lebih memilih apa kata hati dia sendiri.

\section{(3) bahagia}

"Pandai pula Tini mengajak-ngajak orang gembira."(83/1).

Kutipan tersebut menjelaskan sifat Tini yang pandai membuat orang bahagia. Disaat adanya acara bazar Tini bisa membuat orang yang duduk-duduk diam menjadi bahagia dan terhibur saat berbicara dengan Tini.

c. Yah
Sifat-sifat yang ada pada tokoh Yah

adalah suka merayu, ramah dan pengalah.

(1) Merayu

"Suaranya melembut: "Berkurang

lah kasihmu, kalau kita tidak

berkenalan dulu?'.(36/2).

Kutipan tersebut menjelaskan sifat Yah yang suka merayu sebagain wanita penggoda.

(2) Ramah

"Pikiran melayang kembali ke Yah, yang baru ditinggalkan. Benar-benar perempuan, ramah-tamah, pandai bergurau, bercumbu-cumbu". (57/3)

Kutipan tersebut menggambarkan sifat Yah yang ramah, terlihat dari ucapan Sukartono.

(3) Mengalah

"Janganlah nyonya bersedih hati. Saya bukan hendak selama-lamanya dengan dia," kata Yah dengan berlahan-lahan". $(132 / 7)$

Kutipan tersebut menggambarkan sifat Yah yang pengalah, terlihat dari ucapan Yah untuk meninggalkan Sukartono demi Tini.

\section{E. Karakter Tokoh Utama Novel Belenggu Karya Armin Pane Berdasarkan Sikap}

a. Dr. Sukartono

Sikap-sikap yang ada pada tokoh Dr. Sukartono adalah teguh, menghibur, marah, dan ramah.

(1) Teguh

"Imannya sebagai biasa ialah iman dokter."(21/5).

Kutipan tersebut menjelaskan sikap Sukartono yang teguh, bisa menjaga nafsu saat memeriksa pasien, terlihat pada kutipan di atas bahwa imannya adalah iman dokter.

(2) Menghibur 
PONI Ernis : PERBANDINGAN KARAKTER TOKOH UTAMA NOVEL SALAH

ASUHAN KARYA ABDOEL MOEIS DAN BELENGGU KARYA ARMIN PANE

Website : https://jurnal.umj.ac.id/index.php/penaliterasiEmail : penaliterasi@umj.ac.id

"Karena itu sambil memberi recept, katanya katanya dengan lemah lembut: tidak selamanya hari hujan, besok lusa akan panas juga."(22/4).

Kutipan tersebut menjelaskan sikap Sukartono yang pandai menghibur hati pasiennya yang sedang sakit.

(3) Marah

"Tono menghampirinya. Jarinya menunjuk muka Yah. Katanya dengan keras: "Sipatmu tidak dapat berubah, kerbau suka juga kepada kubangnya. Dalam lumpur tempatmu, kembalilah engkau kesana". (121/4)

Kutipan tersebut menggambarkan sikap sukarono yang sedang marah, karena dia merasa kecewa telah dibohongi oleh Yah. Dapat dilihat lagi kutipan yang menggambarkan sikap Sukartono yang sedang marah.

"Dia terkejut, mundur setapak, melihat pandangan Tono.kedua belah tangannya berkepal dihadapan dadanya, menantikan kata Tono". (hal/parg, 120/5)

Kutipan tersebut menggambarkan Sukartono yang sedang marah pada Yah yang telah membohonginya.

b. Tini

Sikap-sikap yang ada pada tokoh Tini adalah marah, egois dan sombong.

(1) Marah

"Karno rajin dan setia, barang kali sebenarnya Tini hendak marahmarah kepadanya, tapi Karno yang menjadi kurban, bukankah Karno pustaka dari dulu".(26/1).

Kutipan tersebut menjelaskan sikap Tini melampiaskan rasa marahnya pada Karno.

\section{(2) Egois}

"Dengan Tini tiada dapat ia bertukar pikiran, bersoal jawab, sindir- menyindir. Bersoal jawab sering juga, yaitu berbantah, untuk perubahan, biar jangan terus menerus saja sama-sama diam". (39/3)

Kutipan tersebut menggambarkan sikap Tini yang egois, tak peduli pada Sukartono lagi, dia lebih suka diam dan sibuk sendiri dengan urusannya.

\section{(3) Sombong}

"Berkenalan! Aku datang kesini bukan untuk berkenalan. Mana perempuan yang baik-baik, suka berkenalan dengan perempuan seperti engkau?". $(131 / 3)$

Kutipan tersebut menggambarkan sikap Tini yang sombong saat berkunjung kerumah Yah, dengan perkataan yang merendahkan harga diri Yah.

c. Yah

Sikap-sikap yang ada pada tokoh Yah adalah setia, suka berpura-pura dan jahat.

(1) Setia

"Memang sejak engkau ku kenal tidak ada temanku lagi, karena itulah aku pindah kesini, biar kita jangan diganggu. Tiadakah engkau kesal, aku Cuma perempuan ....”. (38/10).

Kutipan tersebut menjelaskan sikap Yah berubah menjadi setia demi Kartono, dimana Yah rela pindah agar tidak ada lagi tamu laki-lakinya yang datang menemui Yah.

(2) Suka berpura-pura

"Serasa-rasa menyayat hatiku, pedat didalam hatiku, tiada pernah kuucapkan, tiada pernah ...(katanya dengan lambat-lambat) ada orang tempat aku mencurahkan hatiku, suka mendengarkan kata yang terbit dari hatiku yang sebenarnya... selalu perempuan, perempuan yang mesti menyukai hati orang, apa yang terasa dalam hati kecilku, tiada 
PONI Ernis : PERBANDINGAN KARAKTER TOKOH UTAMA NOVEL SALAH

ASUHAN KARYA ABDOEL MOEIS DAN BELENGGU KARYA ARMIN PANE

Website : https://jurnal.umj.ac.id/index.php/penaliterasiEmail : penaliterasi@umj.ac.id

orang peduli, bukan buat itu orang menghampiri aku, untuk kata dibibir dia datang”. (49/6)

Kutipan tersebut menggambarkan sikap Yah yang suka berpura-pura, Yah hanya perpura-pura bahagia setiap kali harus melayani laki-laki. Padahal dihatinya sangat memberontak hal itu.

(3) Jahat

"Tono, aku benar jahat. Didalam hatiku tertawa sebagai setan tertawa, kalau ada laki-laki terpikat olehku. Kalau dia merendahkan diri tidur dengan aku, aku senang, aku gembira karena dia tertarik kelumpur tempat aku hidup". (50/5)

Kutipan tersebut menggambarkan sikap Yah yang jahat, karena dia akan merasa puas dan bangga jika ada laki-laki yang tidur dengannya.

\section{F. Karakter Tokoh Utama Novel Belenggu Karya Armin Pane Berdasarkan Tingkah Laku}

\section{a. Dr. Sukartono}

Tingkah laku yang ada pada tokoh Dr. Sukartono adalah bahagia dan ingin tahu.

(1) bahagia

"Tenang dan damai rasa hati dokter Sukartono disamput oleh orang sakit, dokter Sukartono biasa duduk sebentar bercakap-cakap.”(16/4).

Kutipan tersebut menjelaskan tingkah laku Sukartono yang bahagia sebagai dokter yang suka bergaul dengan pasien.

(2) Ingin tahu

"Diperhatikannya segala perbuatan

Tini dengan diam-diam, seperti memperhatikan seorang patient."(66/2).

Kutipan tersebut menjelaskan tingkah laku Sukartono yang ingin tahu tingkah laku Tini dengan cara memperhatikan gerak-gerik Tini secara diam-diam.

\section{b. Tini}

Tingkah laku yang ada pada tokoh Tini adalah marah dan menyindir.

(1) Marah

"Tini memandang dengan marah".(35/5).

Kutipan tersebut menjelaskan tingkah laku Tini yang sangat marah pada suaminya yang tidak menjemput dia, padahal Tini telah lama menunggu

(2) menyindir

"Tini tertawa: apa perlunya menyusahkan pikiran? Untuk perkara yang kecil-kecil itu?".(43/6).

Kutipan tersebut menjelaskan tingkah laku Tini yang menyindir kawannya, yang selalu ingin ikut campur urusan rumah tangga Tini.

c. Yah

Tingkah laku yang ada pada tokoh Yah adalah menggoda, membujuk dan kecewa.

(1) Menggoda

"Ketika tangannya hendak ditaruhnya ke atas perut sisakit, tangan sisakit yang selama ini menutup kimononya, menyingkapkan kimono itu".(21/4).

Kutipan tersebut menjelaskan tingkah laku Yah sedang menggoda dokter, walaupun hasilnya sia-sia, karna iman dokter teguh sebagai seorang dokter.

(2) Membujuk

"Setelah diberi minum, sambil ia berlulut, katanya menengadah: ' katakanlah. Apa yang ketahuan?' Dada Kartono lega sedikit".(44/6).

Kutipan tersebut menjelaskan tingkah laku Yah yang pandai membujuk Kartono sehingga merasa lebih tenang.

(3) Kecewa 
PONI Ernis : PERBANDINGAN KARAKTER TOKOH UTAMA NOVEL SALAH

ASUHAN KARYA ABDOEL MOEIS DAN BELENGGU KARYA ARMIN PANE

Website : https://jurnal.umj.ac.id/index.php/penaliterasiEmail : penaliterasi@umj.ac.id

"Perempuan itu menggigit bibir, seolah-olah kecewa, ketika tangan Sukartono menutup kimononya, sambil kata Sukartono dengan pendek saja: "Tidak perlu nyonya buka". (27/4)

Kutipan tersebut menggambarkan tingkah laku Yah yang merasa kecewa akibat penolakan dari Sukartono terhadap dirinya.

\section{HASIL DAN PEMBAHASAN}

\section{(1) Sifat}

Menurut Ruskhan dkk (2008:1302) menyatakan sifat adalah dasar watak (dibawa sejak lahir), tabiat. Berdasarkan pendapat tersebut, dapat disimpulkan sifat adalah rupa, keadaan, ciri, tanda yang tampak pada suatu benda atau keadaan yang menurut kodratnya ada pada suatu orang, dasar watak atau tabiat dari seseorang yang telah dibawa sejak lahir.

\section{(2) Sikap}

Menurut Bruno (dalam Syah, 2007:123) sikap adalah kecenderungan yang relatif menetap untuk bereaksi dengan cara baik atau buruk terhadap orang atau barang tertentu. Ruskhan dkk (2008:1303) Sikap adalah perbuatan dan sebagainya yang berdasarkan pada pendirian, dan keyakinan). Berdasarkan pendapat tersebut, dapat disimpulkan sikap adalah suatu perbuatan dan sebagainya yang dilakukan oleh seseorang berdasarkan pada pendirian, pendapat atau keyakinan dari orang tersebut, yang akan menjadi satu dengan tingkah lalu mereka.

\section{(3) Tingkah Laku}

Menurut Syah (2007:253) laku adalah perbuatan yang menyangkut keanekaragaman perasaan, seperti takut, marah, sedih, gembira, kecewa, senang, benci, was-was, dan sebagainya. Daradjat dkk, (2008:266) menyatakan bahwa Tingkah laku adalah sikap seseorang yang dimanifestasikan ke dalam perbuatan. Hal ini terbukti dari analisis data, terdapat 14 data yang menyatakan tingkah laku tokoh utama yang terdapat dalam novel Salah Asuhan Karya Abdoel Moeis, dengan 12 jenis tingkah laku: merayu, sombong, mengejek, ketertaluan, kasmaran, tobat, waspada, satah tingkah, kekanak-kanakan, meratapi nasib, ragu dan terbawa suasana hati.

\section{KESIMPULAN}

edua novel yaitu novel Salah
Asuhan karya Abdoel Moeis dan
Belenggu karya Armin Pane tidak selalu memiliki karakter yang sama pada tokoh, melainkan ada juga perbedaannya, ada tokohnya yang sama-sama memiliki karakter sombong, egois, pemarah dan penyabar.

1. karakter pada tokoh novel Salah Asuhan karya Abdoel Moeis

\begin{tabular}{|l|l|l|}
\hline No & Karakter & Jumlah \\
\hline 1. & Sifat & 23 \\
\hline 2. & Sikap & 12 \\
\hline 3. & Tingkah laku & 14 \\
\hline
\end{tabular}

2. Karakter pada tokoh novel Belenggu karya Armin Pane

\begin{tabular}{|l|l|l|}
\hline No & Karakter & Jumlah \\
\hline 1. & Sifat & 22 \\
\hline 2. & Sikap & 20 \\
\hline 3. & Tingkah laku & 15 \\
\hline
\end{tabular}

\section{REFERENSI}

Kosasih. 2003. Kompetensi Ketatabahasaan dan Kesusastraan. Bandung: Yrama Widya.

Moeis, Abdoel. 2002. Salah Asuhan. Jakarta: Balai Pustaka.

Moleong, J. Lexy. 2005. Metodologi Penelitian Kualitatif (Edisi Revisi). Bandung: Remaja Rosdakarya.

43 | Pena Literasi 
PONI Ernis : PERBANDINGAN KARAKTER TOKOH UTAMA NOVEL SALAH

Website : https://jurnal.umj.ac.id/index.php/penaliterasiEmail : penaliterasi@umj.ac.id

Muhardi dan Hasanuddin. 1992. Prosedur

Analisis Fiksi. Padang: IKIP Padang Press.

Nurgiyantoro, Burhan. 1995. Teori Pengkajian Fiksi. Yogyakarta: Gadjah Mada University Press.

Pane, Armin. 2008. Belenggu. Jakarta: Dian Rakyat.

Priyatni, Endah Tri. 2010. Membaca Sastra dengan Ancangan Literasi Kritis. Jakarta: Bumi Aksara.

Ruskhan dkk. 2008. Kamus Besar Bahasa Indonesia: Edisi Keempat. Jakarta: Gramedia Pustaka Utama.

Semi, M. Atar. 1988. Anatomi Sastra. Padang: Angkasa Raya.

Siswanto, Wahyudi. 2008. Pengantar Teori Sastra. Jakarta: Grasindo.

Sugiyono. 2010. Metode Penelitian Pendidikan: Pendekatan Kuantitatif, Kualitatif, dan R\&D. Bandung: Alfabeta.

Suhendar dan Supinah, Pien. 1993. Pendekatan Teori Sejarah \& Apresiasi Sastra Indonesia. Bandung: Pionir Jaya.

Syah, Muhibbin. 2007. Psikologi Belajar. Jakarta: Raja Grafindo Perseda 